\title{
Archaeological Excavations at the Ertosh-Dolana Cemetery in the Ahangaron District of Tashkent Region
}

Akhmadali Askarov

Academician,Academy of Sciences of the Republic of Uzbekistan,Tashkent, Uzbekistan

Khalil Matyakubov

Lecturer, PhD, Tashkent, Uzbekistan,Tashkent state pedagogical university named after Nizami,Tashkent, Uzbekistan

Bekhzod Isabekov

Junior Research Fellow, National Archaeological Center,Tashkent, Uzbekistan

\section{ABSTRACT}

Due to the lack of archeological excavations in the Upper Ahangaran Basin,the author conducts archeological excavations in these areas and conducts archeological excavations in the Ertosh-Dolana Cemetery, which belongs to the Qovunchi culture, reflecting the settlement processes of ancient cattle-breeding tribes. The article examines the internal and external structure of burial mounds observed during excavations, burial ceremonies and religious beliefs, as well as the tomb material evidence and tries to determine their social status in the community, occupation, and ethnic groups during their lifetime.

Keywords:

burial mounds, fire-worshiper, temple, kura, toshkol, lahad, baldog, Kovunchi, zoomorph, catacomb, angob.

Article Received: 18 October 2020, Revised: 3 November 2020, Accepted: 24 December 2020

\section{Introduction}

The Ahangaron Valley is one of the regions of Uzbekistan rich in various archeological monuments and underground natural resources. In the life of the ancient and early medieval pastoral tribes of this country, the process of settlement is accelerated, especially in the early Middle Ages, when the metallurgical industry associated with the urban culture and mining of the population developed at a high level. The results of extensive archeological research conducted at this newly opened archeological monument serve as a source for studying the territorial, economic, ethnocultural and religious-ideological development of the Upper Ahangaron Basin, the settlement processes of the region's herders.

\section{The main results and findings}

The exact location of the monument. Ertosh Dolana Cemetery is located on the left bank of the Ertoshsay middle basin, which flows through the gorges of the Chatkal ridge on the 26th kilometer of the Angren-Kokand highway, and is surrounded by mountains. Archaeological excavations in these areas were initially of an exploratory nature, and it was discovered that there were many burial mounds. Tombstones with stone structures, a temple of firefighters, metal smelters of metallurgists, metal stones, archeological objects of the first and advanced Middle Ages were found in this area.

This monument was originally found in the left tributary of the Ertoshsay as a result of the formation of sediments during the irrigation of the gardens occupied by the Chatkal ridge. When these sediments were excavated, it was discovered that there were tombs rich in material evidence at a depth of 4 meters above the ground. Archaeological evidence from the tombs revealed that they belonged to the Qovunchi culture, which belonged to the settled Turkish layer of the Uzbek ethnos. After that, archeological excavations were carried out at the ancient monument.

The cemetery is located on a sloping area with clay soils, the area of which is 1 hectare. This ancient cemetery was named "Ertosh-Dolana" after its natural place.

The upper stone structures of the tombs were removed by the modern villagers and used for the foundations of their buildings, the area was 
leveled and a diamond garden was built. With the consent of the garden owners, the old cemetery area was divided into squares and the monument was explored by digging $1 \times 15,1 \times 20$ meter parallel deep trenches in search of the tomb drom or tomb chamber of the burial mounds. In this way, a total of 7 graves were opened at the ErtoshDolana monument. The tomb burial mounds found in the study were in the form of a catacomb, which was entered through a short narrow passage (dromos). The corridor-dromos was mainly to the south of the tomb chamber, sometimes to the south-west. The entrance to the tomb is an entrance hole, which is covered with a large slab of stone or stones piled on top of each other. The tombs are all oval-shaped in shape. The upper part of the lahad was domed. The tombs consisted of family burial mounds, in each of which several skeletons were found. The skeleton of the head of the family - the man and his wife - is laid on his back, of course, facing east, toward the sunrise. A stone pillow is placed under the skull, and lime or fine gravel is sprinkled on the bottom. In some tombs, a coffin was made of wood and the body was placed in a coffin. Unfortunately, due to the high humidity in the graves, they encounter traces of wood that have not been preserved, or turned to dust. No lime or fine gravel was sprinkled under the bodies in such tombs. The rest of the family, especially the children's skeletons, were buried in an empty space in the grave chamber, where the traditional order was not strictly followed.

From a scientific analysis of the skeletons and material evidence found in these tombs, it can be concluded that this tomb was a family tomb. Similar graves were found in the burial mounds of Dolanabulak, Taipan and Kavar.

The graves found in this monument are as follows:

Grave 1. The subsidence of the ground at the Ertosh Dolana monument is $2 \times 2 \mathrm{~m}$. was determined as a result of excavation in volume. The floor of the tomb is $4 \mathrm{~m}$ above ground level. located at depth. The size of the lahad in this tomb with an oval-shaped catacomb is $2.80 \times 2.70 \mathrm{~m}$. The entrance to the tomb is located to the south of the chamber. It was entered through a dromos. The length of the dromos is about $3 \mathrm{~m}$. The entrance hole from the dromos to the tomb chamber is $50 \times 50 \mathrm{~cm}$. which is covered with a large slab of stone. A skeleton belonging to 3 people was found in the grave. The head of the corpse is facing east and the foot is facing west. The tomb was a family tomb, and it was discovered that one of the skeletons belonged to a man and two to a woman. An iron knife was found on the side of the man's head and a stone tumor on his neck. Around the skeletons of women were found bronze bracelets, beads made of black stones, buckles made of iron, necklaces made of stone.

Eight hand-made pottery vessels were found by the head of the skeletons in this tomb (Figure 1.1). The clay of the vessels is brown, the bottom flat. Two of them are jugs, three are palms (pots), two are butter, and one is a (ritonsimon) dish used in making cheese.

Grave 2. This tomb is $3 \times 3 \mathrm{~m}$ to the east of Tomb 1 as a result of the irrigation of the garden. The size was determined during the excavation of the trench. The pit is $3.5 \mathrm{~m}$ above ground level. when excavated, two larger flat-shaped stones and one smaller smaller shapeless stone were found, which were closed at the mouth of the dromos corridor of the tomb. The diameter of the mouth of the dromos corridor covered with stones is $75 \times 65 \mathrm{~cm}$. The northern side of the mouth of the dromos is $20-25 \mathrm{~cm}$. the floor of the tomb was discovered after excavation. The grave floor is $3.75 \mathrm{~m}$ above ground level. located below. The lahad in this tomb is oval in shape, measuring $2.7 \mathrm{~m}$ from north to south and $3.05 \mathrm{~m}$ from west to east.

When this grave was cleared of poly soil, 4 skeletons were found. The skeletons had rotted to dust and were in poor condition. Looking at the skeletons, their gender could not be determined. Their head is on the east side and their feet are on the west side, lying on their backs. In the tomb, a stone was placed on the head of the body, while the bottom was covered with small gravel. Stone and gravel served as a curtain separating the 
deceased from the holy land. This testifies to the belief of our ancestors in the world and the preservation of Zoroastrian traditions. An iron knife, an iron ring, a bow and arrow, a stone and beads were found in the grave.

On the head side of the skeletons are placed 6 handmade ceramic vessels (Fig. 1.2). Three of them consist of palms, two of fat, and one of pans. The clay of the vessels is brown, and the surface is light brown and black in color.

Tomb 3. North of Tomb 1, 2x2 m. As a result of digging a trench of the same size, the tomb was opened. Lahad poly is $3.85 \mathrm{~m}$ above ground level. located in the lowlands. It is oval in shape, $2.5 \mathrm{~m}$ from north to south and $2.3 \mathrm{~m}$ from west to east. Horizontally from west to Lahad, descending height $60 \mathrm{~cm}$. width $75 \mathrm{~cm}$. entered from a corridor of about $3 \mathrm{~m}$ in length. The corridor in front of Lahad is $55 \mathrm{~cm}$ high, $74 \mathrm{~cm}$ wide and 25 $\mathrm{cm}$ thick. covered with a solid stone. Dromos stone $25 \mathrm{~cm}$. located at an altitude of lahad poli. When the sunken tomb was cleared of soil, it was discovered that there were skeletons belonging to 5 deceased who had been placed on the waterfall. We concluded that all the skeletons were chaotic and piled on top of each other, and that the tomb had been used several times to bury the dead. Around the skeletons were found "stone" (surmatosh), jewelry made of small black stones, and also bronze jewelry.

A total of 4 ceramic pottery samples found in the tomb were handmade, consisting of two jugs and two palms (Figure 1.3).

Tomb 4. In the north-west of the cemetery, the second trench below is $1.5 \mathrm{~m}$. when excavated to a depth, the top of this tomb was perforated. This tomb, unlike the others, was not covered with earth. Its dromedary is oriented from south to east and is $3 \mathrm{~m}$ long, $70 \mathrm{~cm}$ wide and $80 \mathrm{~cm}$ high. The Dromos corridor is $2.6 \mathrm{~m}$ above ground level. sloping to the depths and descending towards the lahad. Lahad is placed in a shape perpendicular to this dromos. The entrance door from Domos to Lahad is $60 \times 60 \times 15 \mathrm{~cm}$. covered with solid slab stone.
The ceiling of the tomb chamber is oval in shape. Its height to the floor is $2.80 \mathrm{~cm}$. During the process of clearing the tomb, it was discovered that there were three human skeletons in the tomb. Their head is extended to the east, and their feet are extended to the west, lying on their backs. Their heads are turned to the left (west). The skeletons have long since rotted and turned to dust due to the infiltration of snow, rainwater, erosion of the roof soil of the shed, and high levels of moisture. The preserved bones were also in a very bad condition. It was not possible to determine their gender. Iron knives and bow arrows were found in this tomb, all of which had lost their original condition. Five pieces of pottery were found on the head of the skeletons in the tomb (Figure 1.4).

Tomb 5. This tomb is located north of Tomb 1, which was discovered as a result of the opening of the corridor (dromos) traces from the western corner of the trench during the excavation of Trench 7. The internal structure of the tomb is no different from Tomb 4 . The catacomb poly is 4.25 $\mathrm{m}$ above the ground level. located in the lowlands. The catacomb is oval in shape, measuring $2.72 \mathrm{~m}$ from north to south, $2.8 \mathrm{~m}$ from east to west, and $1.3 \mathrm{~m}$ from the highest point of the dome. On the south-western side of the tomb is $3.5 \mathrm{~m}$ long and $0.65-0.75 \mathrm{~cm}$ in diameter. dromos. The corridor was inclined to the tomb, and a solid stone was placed near the entrance to the tomb.

A skeleton belonging to two people was found on the floor of the room. Their condition is not well maintained. Both are lying on their backs.

During the burial of the corpse by the head of the skeletons in the tomb, nine hand-made pottery and metal fragments were found buried by his teammates. One of the pottery vessels found consisted of a jug, four pots, three bowls of oil, and one bowl (Fig. 1.5).

Grave 6. During the excavation of the sixth trench, a corridor of dromos was encountered in the eastern part of the trench. The entrance to the tomb was oriented from south to northeast, and during excavation a stone was found placed in the 
mouth of the dromos. The place is covered with two $20 \mathrm{~cm}$ slabs of stone. The length of the dromos path is $3 \mathrm{~m}$, width $80 \mathrm{~cm}$, height $70 \mathrm{~cm}$. Tomb chamber from Dromos - entrance to the tomb $60 \times 70 \mathrm{~cm}$. A pit was dug at the top for the tomb to sink. Its poly is located at a depth of 4 meters above ground level. The ceiling of the tomb chamber is a dome, the history of which is oval. Its height is $1.30-1.35 \mathrm{~m}$. The tomb is 2.61 $\mathrm{m}$ from north to south and $2.54 \mathrm{~m}$ from east to west. During the process of clearing the grave, three human skeletons were found, which were kept in very bad condition. During the excavation, it was discovered that this grave was used several times for burying the dead. The tomb was covered with gravel, and the bones of the first buried were later laid on a gravel bed. Other corpses were placed in the vacant lot. Iron knives and beads were found around the skeletons. Based on this, we concluded that one of the corpses belonged to a man and the other to a woman.

A total of 4 pottery vessels were found in this tomb. Three of them consist of a palm and one of a cup (Fig. 1.6).

Grave 7. During the excavation of the grave trench, a dromos corridor was found. The dromos comes from the south and is $3.50 \mathrm{~m}$ in a sloping position. When excavated from the Dromos corridor, it was discovered that it was a catacomb tomb, but the tomb turned out to be a sunken tomb. The height of the tomb was $4.30 \mathrm{~m}$ above the ground. The tomb is catacomb-shaped and the height of the dome is $1.25-1.35 \mathrm{~m}$. The size of the tomb is $2.50 \mathrm{~m}$ from north to south and $2.80 \mathrm{~m}$ from east to west. When the tomb was cleared of dust, it became clear that this tomb had been used several times to bury the dead. Because all the skeletons in the tomb were scattered randomly. The height of the dromos stone is $65 \mathrm{~cm}$. width 77 $\mathrm{cm}$ and $25 \mathrm{~cm}$ above the ground level. was located at an altitude of. A total of four skeletons were found in the tomb.

A total of seven handmade pottery vessels were found in Tomb 7 (Figure 1.7). 2 of them are palms, the rest are jugs. The dishes are all handmade.
A total of 43 archeological pottery items were found during the study of the Ertosh Dolana monument. All the pottery found was handmade without wheels. Some of them are elegantly made, some are very rough. Most ceramics have black, red, and light brown angobes on the inside and outside. We have divided the ceramics into the following types depending on the shape and structure.

Jug. The jars were divided into the following groups depending on the structure of the neck, with or without a handle.

1) Egg-shaped jars with large single-stalked buds (1 piece) (Fig. 2.1). Their lips, like the first type, are turned outwards. The necks are elongated, with a vertical line drawn on the handle of one of them.

These symbols are interpreted in the form of one, two, sometimes three lines in ceramic vessels. Their pictorial basis is unknown because they are too schematic. Given the location of this group of characters, it can be said that they are associated with magic. In the process of studying the jar, we came to the conclusion that this sign was a distinctive mark of the potter.

2) Large jugs without handles (1 piece). Their lips are turned outwards. In an oval shape, the throat is elongated, with a series of lines drawn around the circumference as it passes into the abdomen. He has an "X" stamp on his shoulder (Figure 2.2).

3) A jug of large and small size, a jug with a tapshaped mouth and 4 jugs. This is a characteristic feature of the pottery complex of the Qovunchi -2 stage. Their mouths are slightly turned outwards and their folds are erect. In such jars are mounted vertically in the form of a semicircular cane. One end of the bald is attached to the shoulder and the other end to the neck. The surface of the jars is dark brown and black, some are dark red (Fig. 2.4). The shoulder portion of one of the vessels is lined with a series of parallel stripes around the circumference (Fig. 2.5,6). In a few of the jars, lines were drawn around the shoulder using a ceramic knife. On the abdomen of one of them, next to the handle, there is an " $\mathrm{X}$ " (cross) mark 
(Figure 2.2,3). Crosses are mounted on or under the top of the jugs and handles, i.e. where zoomorphic handles are usually located. So we can see the connection between the cult of the ram and the signs of the sun.

The cross-shaped symbols, which intersect in a cross-shaped manner, are a symbol of the sun, which shows the worship of the sun and fireworship by the owners of this culture. This indicates that the people of the region considered the sun sacred in ancient times. This means that the sun and fire played an important role in the religious beliefs of the people of the region. These processes are also reflected in the material culture of the population. Many vessels with such a sign were found.

4) A pitcher (1 piece) was found. The body of the jug is spherical, the base is flat, and the neck has a snout. The surface of his mouth, which is turned inwards and outwards, is dark black. A dark black circular pattern is placed on a white ribbon along the circumference of the scapula (Fig. 2.7). Vessels of this shape, equipped with two verticalshaped handles on their shoulders, were found in Qovunchitepa, dating back to the Qovunchi 2 period. Hence, such jars are common in Qovunchi culture and periodically characterize Qovunchi 2 period.

5) A sieve was found. The outer surface and the lip side of the neck are brown. The triangularshaped lip is turned outwards. A semi-circular cane is mounted vertically on it. One end of the bald is attached to the shoulder and the other end to the lip of the vessel. Parallel lines are drawn around the circumference of the narrow neck section. On the abdomen, a dark red half-moon pattern is drawn around the circumference of the white ribbon. The narrowed, shortened bottom of the strainer consists of $5 \mathrm{~mm}$ holes (Fig. 2.8). Similar vessels in the same shape and decoration are also found in wood materials. Such dishes are rarely encountered in the Qovunchi culture. In the stone materials, this vessel is mistakenly called "riton". Because this container is a strainer, that's why we call it a strainer. It was this strainer that was used to make cottage cheese.

Pot. Pots were found in total (15). According to the shape of the formation is divided into the following types: the long abdomen of the neck is divided into spherical, short-necked ovate palms.

1) Spherical pots (12 pieces) were found with a long belly at the neck. Everything is handmade and the surface and interior are painted in reddish black. According to the structure of their mouth, the tip of the lip is turned inwards, the lips of the others are shaped like a sharp triangle (Figures $2.9-10,11,12,13,14,15,16,17,18,19,20,22)$. Stripes are drawn along the shoulder circumference of several of the palms (Figures 2.10,13,14,15,22). The neck and shoulder portion of one of the pots is lined with parallel stripes around the circumference. Another pots has a line drawn around the shoulder and the letter " $\mathrm{X}$ " is stamped on the abdomen (Figure 2.18).

Short-necked ovate pots (3) were found. The surface of two of them is embroidered. The labia are triangular in shape, the outer surface and the inner part of the neck are reddish-black in color. The shoulder portion of the first palm is lined with a series of parallel stripes around the circumference. They have a reddish-white ribbon around their necks, and two rows of semicircular patterns in dark black on top. The neck and shoulders of the second palm are lined with parallel lines around the circumference. Beneath it is a white ribbon, the inside of the ribbon is embroidered in the form of a comma with red piston flowers. Its bottom is painted dark red to the bottom of the pot.

Patterns in the form of commas and pea symbols were found in pottery from Gairattepa in the IIIIV centuries AD. Some forms, such as ringshaped vessels decorated with red, dark brown patterns, are believed to be typical of the II-III centuries $\mathrm{AD}$. The ornaments of the jars were also found to be similar in the army areas. Therefore, the pattern in the form of commas and squares covers pottery of the III-IV centuries AD. Such patterns, flower pots, strainers, palms were found 
in large numbers (Figures 2.7,8,20,23), their periodic date can be determined as II-IV centuries. The structure, color, shape of these palms are very similar to the above patterned vessels. The blunt lip of the palm resembles a glass turned outwards. A reddish-black color is poured on one side of the surface of the vessel. Palms are made from a mixture of coarse clay mixed with limestone and sand. By placing this palm on the coals, the liquid appears to be cooked. Because traces of fire are stored in its tag (Figure 2.11).

mug. The mugs were found in total (12 pieces). From the first half of the first millennium, pottery with a zoomorphic handle, which is very characteristic of the Tashkent oasis and the Middle Syrdarya, can be found in many monuments. These mugs have the main character that periodically defines the Qovunchi 2 culture. These mugs are divided into the following types according to their construction and structure: the first is a cylindrical neck, the lips are vertical, the second is a short neck of the mug, the abdomen is circular.

1) The neck part is cylindrical in shape, the lips are vertical cups (10 pieces). It is elegantly handmade and the surface is reddish or black in color. The neck of the mug is cylindrical, the lips are straight, the abdomen is noxious. In some, a line is drawn around the shoulder circumference, while in others, parallel lines are drawn. The ankle connecting the neck and shoulder is vertical.

The vertical handles on the ballast vessels are designed in a zoomorphic manner. Some of the jars have a picture of an animal on the handle. All four of the mugs have a horned ram on the handle. The construction, structure and color of the dishes are close to each other (Figures 2.24,27,28,30,34). The peculiarity of the Qovunchi 2 culture is that animal-shaped pots are very common in pottery handles. The ram shape is more common among these animals. The image of a ram can be associated with sun signs. Such jars are typical of the 2nd stage of Qovunchi culture.

Although the ideological superiority of fireworship was evident in religious and cultural life, religious tolerance had its place in the spiritual life of the Syrdarya middle basin society. The cult of God, totemism and its belief in the horse, ram, and magic, which are more characteristic of the Turkic ethnic communities than in the material and spiritual world of the Qovunchi culture, still persisted among the general public. Exactly these cases are reflected in mugs, ceramic pots.

A line is drawn around the shoulder circumference of the cups. The handle, which is light red in color, is broken (Figure 2.31).

The mugs are elegantly handmade and the surface is reddish or black in color. The neck of the mug is cylindrical, the lips are straight, the abdomen is noxious. The ankle connecting the neck and shoulder is vertical. Some of the jars have a picture of an animal on the handle. The handles of some vessels were broken (Fig. 2.25,26). Most of the rams are painted on the handles of the mugs. Unfortunately, in one of the vessels, the muzzle of the ram on the handle was broken. However, its branches have been preserved (Fig. 2.32). A horse statue mounted on a half-ring-shaped handle is broken and missing. Only its ears and path are preserved on the handle (Fig. 2.29).

There are many zoomorphic vessels (Ungurli-asar, Tompak-asar, Kara-asar) depicting the head of a horse or a dog in their handles. Zoomorphic handle vessels were widespread in the Sarmatian culture in the I centuries AD along the North Caucasus, Crimea, Lower Volga. This vessel shows exactly the sphere of influence of the above cultures in these regions.

2) Mugs with a short abdomen and a round neck.

The lips of the mug are flatter, the abdomen is spherical in color. One draws a series of parallel lines around the shoulder circumference. A horizontal parallel line is drawn on the handle. The vertical handle has a circular shape with no markings. (Figure 2.33.35).

korakumgon. Among the tomb pottery there are 3 groceries, some of which have been broken down to us, some of which have reached the whole condition. Homogeneous mixtures are mixed into the clay of the dishes. Mixtures consist 
of white sand and crushed stone particles, and vessels made of such mixtures are heat-resistant, able to retain heat for a long time.

That is why such mixed clay is used to make pottery. The color of the container is black, with burnt marks on the surface. The waist has a handmade rough handle (Figures 2.36,37,38). In general, the type of kitchen pottery increases at this stage. Their surface is decorated with red or black paint, among which zoomorphic handle mugs and jugs are the main types of Qovunchi 2 ceramic complex. Spherical round-shaped ceramic pots are common in the Qovunchi 2 complex. The handle of these cauldrons is ring-shaped, just like the copper cauldrons of the Jetiasar culture, whose periodic date is set to the III-IV centuries AD.

Sand-pitcher. A total of 2 such vessels were found.

The sand-pots are all hand-roughened, baked by adding white sand and crushed stone particles to their clay. There were traces of fire on the outside. All of the sand-jars are brittle (Fig. 2.39). Made by hand, they used white sand and crushed stone particles in their mud. In ancient times, his belly was cracked, and this pitcher was not thrown away, but was made by a master potter. This sandpit differs from the previous ones in that the liquid capacity is wider and lower (Fig. 2.40).

Koracha. A total of 1 koracha was found. It is in the form of a jar, made of white sand mixed with crushed stone powder. The inside is light brown, the outside is black. One of the dishes looks small. In this tiny dish, food is cooked for the baby (Figure 2.41).

Tavacha. 1 such vessel was found.

One of the hand-rough ones has a small handle on the lip. These dishes are in the form of bowls for frying, with white sand and crushed stone particles (dresva) added to its dark black clay. Such containers retain heat for a long time (Figure 2.42). Such ceramic pans are also common in the Qovunchi 1-2 ceramic complex.

Kosa (bowl). A total of 1 bowl was found. In the ceramic complex of this stage a large number of conical deep coppers of various sizes and shapes were found. Some of them are narrow-walled, and sometimes there are ring-shaped muskets between them. Everything is elegantly handmade. Their brick-colored interior and exterior are black. The lip of the bowl is sharply vertical, embroidered in the form of two rows of bubbly ribbons around the outer circumference (Fig. 2.43).

All the pottery found as a result of the analysis of these objects belong to the Qovunchi culture, which indicates that the indigenous population played an important role in the formation of the Uzbek ethnogenesis.

Military weapons. Paikons, daggers and knives were found in the weapons.

Paykon. Paykon bullets were found in 2 graves. They are all made of iron. All of the paykons were splintered, and wood debris was preserved in the splinter tube. The edges of the warheads of the paykons lost their original position over time (Fig. 3.41.42).

Iron knives are found in many, their size is $8-20$ $\mathrm{cm}$. range. 8 such knives were found (Figs. $3.17,18,19,20,21,22,23,24)$ whose blades were one-sided and only one had a double-edged blade. The handles of the knives appear to have been hammered, only one of which retains traces of the nails that fasten the handle.

Jewelry and ornaments. Many buckles, rings, beads, earrings, amulets were found in this monument.

Buckle. No remnants of clothing were found in the graves due to high humidity. However, lumbar buckles were found (Figs. 3.36,37,38,40). The buckles are almost all made of iron, the shape consists of a circular frame and tongues. One of the buckles is delicately crafted, decorated with bronze, in which traces of fabric are also preserved (Fig. 3.39).

4 rings were found in the ornaments, which were made of iron (Figures 3.32,33,34,35). In the form of a circle, two were found intact, and the rest in a broken state.

The beads are made of various precious stones. These include coral, jade, turquoise lazurite, and black coral stones (Figure 3.1-16). Bronze and 
copper beads are also common (Figures $3.12,13,27,28)$. A bouquet of corals was found in one of the tombs, the necklace being preserved in its original state (Figure 3.4). Among the jewels were earrings made of bronze in the shape of almonds, with a hole made in the top of it for threading (Fig. 3.27,28). Two stone tumors were found in the material evidence complex of the monument (Figures 3.25,26). They are elongated, carrot-shaped, with a threaded hole at the top.

\section{Conclusion}

The discovery and study of a number of new burial mounds belonging to the Qovunchi culture within the territory of the Upper Ahangaron Basin testifies to the rapid penetration of the Turkic ethnic communities into the ancient, especially in the early Middle Ages, mountainous areas of the Ahangaron Valley. The Ertosh Dolana cemetery is a clear example of this. Due to the rich material evidence found in the graves, they belong to our cattle-breeding Turkic ancestors, which indicates that the process of settlement in their lives gradually became widespread throughout antiquity throughout modern Uzbekistan.

Through the study of Ertosh Dolana cemetery, information about burial structures, their structure, burial ceremonies, customs, location of skeletons, religious views were analyzed.

It was also found that all the pottery found in the tomb was handmade, their structure, shape, period. As a result, it became clear that all the dishes belong to the 2nd stage of the Qovunchi culture, which dates back to the II-IV centuries AD.

\section{References:}

[1] Ю.Ф.Буряков,

М.Р.Қосимов, О.В.Ростовцев. Тошкент областининг археологик ёдгорликлари. -Тошкент, 1975.-6.72.

[2] Аскаров А. Инамов О. Исабеков Б. Комплекс погребальных памятников “Дуланабулак» в верховьях реки Ахангарана и его изучение”. // Традиции Востока и Запада в античной культуре Средней Азии, - Ташкент, 2010. - С. 73-83. www.psychologyandeducation.net
[3] Исабеков Б.И. “Қовунчи маданияти этник гурухлари Чотқ ол ва Қурама тоғ чўқ қ иларида. // «ЎЗМУ хабарлари” журнали, 2018 йил 1/2-сон. 32-35 бет.

[4] Бойс Мэри. Зороастрийцы. Верования и обычаи. - Москва. Наука, 1988.-С. 303.

[5] Сычева. Н. С. Керамика Кара-тепе//Новые находки на Кара-тепе в старом Термезе. М. ,1975.- С. 127-128. Рис. 52.

[6] К.М.Байпаков, А.Н.Подушкин. Памятники земледельческо-скотоводческой кутьтурь Южного Казахстана.-Алма-Ата.1989.C.144.

[7] Д.А.Алимова, М.И.Филанович.Тошкент тарихи (қ адимги даврлардан бугунги кунгача).-Тошкент.2009.14.бет.

[8] М.Левина Керамика нижней и средней Сьрдарьи в I тьсячелетии н.э.Москва.1971.-С.106.

[9] В.И.Козенкова.Гайрат-тепа,СА, 1964,N;3,С.232,рис.6,12.

[10] Древний город Средней Азии.Краткие тезисы докладов заседания конференции, посвщенной полевым исследованиям в области архелогии,8-11 апреля 1973 г.Л.,1973.

[11] Литвинский Б.А.Джунский могильник и некоторые аспекты кангюйской проблемы.-CA,1967.N;2.

[12] Литературу по этому вопросу см.Б.А.Литвинский.Кангюйскосарматский фарн.Душанбе.1968.-С.3-4

[13] Иномов .У.,Исабеков Б.И.Илк Ўрта асрларда ўзаро локализатцияси Тошкент вохасидаги архелогик маданиятларнинг ўзаро локализацияси. // "ЎЗМУ хабарлари" журнали, 2017 йил 1/4-сон

[14] Филанович М.И. Древняя и средневековая история Ташкента в археологических источниках. Узбекистан, 2010. - С. 11.

[15] Григорьев

Г.В.Келесская степь...с.55;Бернштам А.Н.Чуйская долина...-С.127. 
[16] Л.М.Левина Керамика нижней и средней Сьрдарьи в I тьсячелетии н.э. Москва.1971.с.

[17] Отахўжаев А. Илк ўрта асрлардаги Чоч тарақ қ иётига Суғ днинг таъсири. “Ўзбекистон пойтахти Тошкент 2200 ёшда. Халқ аро илмий конференция материаллари". - Тошкент, 2009. - Б. 94-98.
[18] К.М.Скалон.Изображение животных на керамике сарматского периода.”Труды отдела первобытной культуры ГЭ”,т.1.Л.,1941.стр.173 и сл;Е.Г.Кастананян.Сарматские сосуды из Тритаки.СA,XV.1951,-- С.248 